\title{
GAMBARAN CT SCAN KEPALA PADA PENDERITA CEDERA KEPALA RINGAN DI BLU RSUP Prof. Dr. R. D. KANDOU MANADO PERIODE 2012 - 2013
}

\author{
${ }^{1}$ Miranda Esther Irene Manarisip \\ ${ }^{2}$ Maximillian Ch. Oley \\ ${ }^{2}$ Hilman Limpeleh
}

\author{
${ }^{1}$ Kandidat Skripsi Fakultas Kedokteran Universitas Sam Ratulangi Manado \\ ${ }^{2}$ Bagian Ilmu Bedah Fakultas Kedokteran Universitas Sam Ratulangi Manado \\ Email: mirandamanarisip@rocketmail.com
}

\begin{abstract}
Head injury is a medical injury that is directly or indirectly in the head which effects the injury to the scalp, skull fracture, tear on the lining of the brain, damage of the brain tissue, and neurological disorders. Head injury considered minor if the degree of total GCS is $14-15$. Purpose: The research is aimed to get the CT Scan appearance on the minor head injury based on sex, age, and the causes on Surgery Department og BLU RSUP Prof. Dr. R. D. Kandou Manado period 2012 - 2013. Method: This research used descriptive retrospective methode by collecting data in Medical Record department of RSUP Prof. Dr. R. D. Kandou Manado. Conclusion: Among 105 cases of minor head injury, only 89 cases that met the criteria of inclusion study. Patients with minor head injury were mostly men, as many as $76 \%$ with largest age group range $>15-20$ years by 26\%. The causes of minor head injury that most found was traffict accident as many as $73 \%$. There were $11 \%$ minor head injury patients who had normal picture of CT Scan result, whreas the most abnormal CT Scan appearance was ICH as many as $34 \%$.
\end{abstract}

Keywords : The Skull CT Scan appearance, Minor head injury

\begin{abstract}
Abstrak: Cedera kepala adalah cedera mekanik yang secara langsung atau tidak langsung mengenai kepala yang mengakibatkan Luka di kulit kepala, fraktur tulang tengkorak, robekan selaput otak, dan kerusakan jaringan otak itu sendiri, serta mengakibatkan gangguan neurologis. Cedera kepala dikatakan ringan bila derajat GCS total adalah 14-15. Tujuan: Penelitian ini bertujuan untuk mengetahui gambaran CT Scan kepala pada penderita cedera kepala ringan berdasarkan jenis kelamin, umur dan penyebab di IGD Bedah BLU RSUP Prof. Dr. R. D. Kandou Manado periode 2012 - 2013. Metode: Metode yang digunakan adalah metode deskriptif retrospektif, dengan mengumpulkan data di bagian Rekam Medik RSUP Prof. Dr. R. D. Kandou Manado. Simpulan: Dari 105 kasus cedera kepala ringan, hanya 89 kasus yang memenuhi kriteria inklusi penelitian. Pasien cedera kepala ringan yang paling banyak adalah laki - laki sebanyak 76 \% dengan kelompok umur terbanyak >15 - 20 tahun sebanyak $26 \%$. Penyebab cedera kepala ringan yang paling sering adalah kecelakaan lalu lintas sebanyak $73 \%$. Sebanyak $11 \%$ pasien cedera kepala ringan memiliki hasil CT Scan dengan gambaran yang normal, sedangkan gambaran CT Scan abnormal yang paling banyak adalah ICH sebanyak $34 \%$.
\end{abstract}

Kata kunci: Gambaran CT Scan Kepala, Cedera Kepala Ringan

Cedera kepala merupakan salah satu penyebab kematian utama dikalangan usia produktif khususnya di negara berkembang. ${ }^{1}$
Distribusi Soetom (2002), distribusi kasus cedera kepala terutama melibatkan kelompok usia produktif antara 15-44 tahun 
dan lebih didominasi oleh kaum laki-laki dibandingkan dengan perempuan. ${ }^{2}$ Di Amerika Serikat pada tahun 1990 dilaporkan kejadian cedera kepala 200/100.000 penduduk pertahun. ${ }^{1}$ Insiden cedera kepala di Eropa pada tahun 2010 adalah 500 per 100.000 populasi. ${ }^{3}$ Insiden cedera kepala di Inggris pada tahun 2005 adalah 400 per 100.000 pasien per tahun. ${ }^{3}$ Gururaj et al pada tahun 2004 mendapatkan bahwa insiden cedera kepala di India setiap tahunnya adalah 160 per 100.000 populasi. ${ }^{3}$ Menurut WHO, kecelakaan lalu lintas di dunia tahun 2004 telah merenggut satu juta orang setiap tahunnya sampai sekarang dan dari 50 juta orang mengalami luka dengan sebagian besar korbannya adalah pemakai jalan yang rentan seperti pejalan kaki, pengendara sepeda motor, anak-anak, dan penumpang. ${ }^{5} \mathrm{Di}$ Indonesia sendiri angka kecelakaan lalu lintas masih cukup tinggi. Pada tahun 2003 kasus cedera kepala akibat kecelakaan lalu lintas sebanyak 13.399 kejadian. Dari jumlah yang ada sebanyak 9.865 orang meninggal dunia, 6.142 orang cedera berat dan 8.694 cedera ringan. Di negara berkembang seperti Indonesia, perkembangan ekonomi dan industri memberikan dampak frekuensi cedera kepala cenderung semakin meningkat, dan merupakan salah satu kasus yang paling sering dijumpai di ruang gawat darurat rumah sakit. $^{2}$

Berdasarkan beratnya, cedera kepala dibagi atas ringan, sedang dan berat. $^{4}$ Pembagian ringan, sedang dan berat ini dinilai melalui Glasgow Coma Scale (GCS). GCS merupakan instrument standar yang dapat digunakan untuk mengukur tingkat kesadaran pasien trauma kepala. ${ }^{5}$ Yang dinilai dari pemeriksaan ini adalah tingkat penurunan terbukanya mata, respon verbal, dan respon motorik dari penderita cedera kepala. Cedera kepala dikatakan ringan bila derajat GCS total adalah 14-15, sedang bila derajat GCS total adalah 9-13, dan berat bila derajat GCS total 3-8.

Computerized tomography scanning merupakan modalitas diagnostik penting dalam praktek neuradiologi dan merupakan langkah utama untuk menunjukkan adanya lesi intrakranial, perluasan serta lokasinya. Pemeriksaan ini merupakan metode diagnostik standar terpilih (gold standart) untuk kasus cedera kepala mengingat selain prosedur ini tidak invasive (sehingga aman), juga memiliki kehandalan yang tinggi. ${ }^{6}$

Pasien dengan cedera kepala ringan pada umumnya dapat mengikuti semua perintah dalam penilaian GCS. Bahkan pasien dengan cedera kepala ringan bisa dikatakan sadar penuh atau tidak mengalami penurunan kesadaran. Keadaan yang seperti ini sering dianggap remeh sehingga terkadang pemeriksaan lebih lanjut sering terlewatkan dan bahkan tidak dilakukan. Hal ini membuat pasien dengan cedera kepala ringan kadang-kadang terjun ke keadaan yang lebih buruk, jika terdapat lesi intrakranial.

\section{METODE}

Penelitian ini bersifat deskriptif retrospektif dengan menggunakan data sekunder yaitu catatan medik penderita, yang dilakukan di bagian Rekam Medik RSUP Prof. Dr. R. D. Kandou Manado dan dilaksanakan pada Januari 2014. Subjek penelitian adalah semua penderita Cedera Kepala Ringan yang dirawat di IGD Bedah BLU RSUP Prof. Dr. R. D. Kandou Manado periode 2012-2013. Data yang dikumpulkan dari catatan medik yaitu jenis kelamin, umur, penyebab, gambaran CT Scan kepala, dan penanganan yang diberikan. Selanjutnya dilakukan pengolahan data, analisis data, dan disajikan dalam bentuk laporan penelitian.

\section{HASIL}

Berdasarkan data yang diperoleh dari bagian Rekam Medik di BLU RSUP Prof. Dr. R. D. Kandou Manado periode 2012 2013 ada 206 pasien cedera kepala yang masuk di RSUP Prof. Dr. R. D. Kandou Manado. Sebanyak 105 pasien mengalami cedera kepala ringan, 64 pasien mengalami cedera kepala ringan dan 37 pasien mengalami cedera kepala berat. Dari 105 kasus cedera kepala ringan, hanya 89 kasus yang memenuhi kriteria inklusi penelitian. 
Manarisip, Oley, Limpeleh; Gambaran CT Scan Kepala pada Penderita Cedera Kepala...

\section{Jenis Kelamin}

Berdasarkan hasil penelitian, didapatkan jumlah penderita laki-laki sebanyak 68 penderita $(76 \%)$ dan perempuan sebanyak 21 penderita (24\%) (Tabel 1).

Tabel 1. Distribusi penderita cedera kepala ringan berdasarkan jenis kelamin

\begin{tabular}{ccc}
\hline Jenis Kelamin & $\mathbf{n}$ & $\mathbf{\%}$ \\
\hline laki-laki & 68 & 76 \\
perempuan & 21 & 24 \\
Total & $\mathbf{8 9}$ & $\mathbf{1 0 0}$ \\
\hline
\end{tabular}

\section{Umur}

Berdasarkan hasil penelitian, didapatkan jumlah penderita yang paling banyak adalah kelompok umur $>15-20$ tahun dengan jumlah penderita 23 orang (26\%). Jumlah penderita yang paling sedikit yaitu kelompok umur $>40-45$ tahun dan $>55$ - 60 tahun dengan jumlah penderita 2 orang (2\%). (tabel 2)

Tabel 2. Distribusi penderita cedera kepala ringan berdasarkan umur

\begin{tabular}{ccc}
\hline Umur (tahun) & $\mathbf{n}$ & $\mathbf{\%}$ \\
\hline $13-15$ & 7 & 8 \\
$>15-20$ & 23 & 26 \\
$>20-25$ & 21 & 23 \\
$>25-30$ & 5 & 6 \\
$>30-35$ & 9 & 10 \\
$>35-40$ & 5 & 6 \\
$>40-45$ & 2 & 2 \\
$>45-50$ & 3 & 3 \\
$>50-55$ & 6 & 7 \\
$>55-60$ & 2 & 2 \\
$>60$ & 6 & 7 \\
Total & $\mathbf{8 9}$ & $\mathbf{1 0 0}$ \\
\hline
\end{tabular}

\section{Penyebab}

Penyebab cedera kepala paling sering adalah kecelakaan lalu lintas (KLL) sebanyak 65 kasus (73\%). Sedangkan yang paling sedikit akibat dibacok sebanyak 1 kasus (1\%) (tabel 3)
Tabel 3. Distribusi penderita cedera kepala ringan berdasarkan penyebab

\begin{tabular}{ccc}
\hline Penyebab & $\mathbf{n}$ & $\mathbf{\%}$ \\
\hline KLL & 65 & 73 \\
Terjatuh & 18 & 20 \\
Dipukul & 5 & 6 \\
Dibacok & 1 & 1 \\
Total & $\mathbf{8 9}$ & $\mathbf{1 0 0}$ \\
\hline
\end{tabular}

\section{Gambaran CT Scan Kepala}

Dari 89 kasus yang ada, sebanyak 10 kasus memiliki gambaran CT Scan kepala normal. Dari 79 kasus dengan gambaran CT Scan abnormal, gambaran intracranial haemorrhage (ICH) merupakan yang paling banyak dengan jumlah 30 (34\%). Subarachnoid haemorrhage (SAH) merupakan gambaran yang paling sedikit dengan jumlah 1 kasus (1\%). (tabel 4)

Tabel 4. Distribusi penderita cedera kepala ringan berdasarkan gambaran hasil CT Scan kepala

\begin{tabular}{ccc}
\hline $\begin{array}{c}\text { Gambaran CT } \\
\text { Scan }\end{array}$ & $\mathrm{n}$ & $\%$ \\
\hline $\begin{array}{c}\text { EDH } \\
\text { FRAKTUR } \\
\text { BASIS CRANII }\end{array}$ & 10 & 11 \\
ICH & 30 & 34 \\
LESI MULTIPLE & 25 & 28 \\
SAH & 1 & 1 \\
SDH & 5 & 6 \\
NORMAL & 10 & 11 \\
Total & $\mathbf{8 9}$ & $\mathbf{1 0 0}$ \\
\hline
\end{tabular}

\section{Penanganan}

Dari 79 kasus dengan gambaran CT Scan abnormal, ada 47 kasus yang dilakukan tindakan operasi dan 32 kasus 
tidak dilakukan operasi. Untuk 10 orang dengan gambaran CT Scan kepala normal diberikan penangan konservatif. (tabel 5)

Tabel 5. Distribusi penderita cedera kepala ringan berdasarkan penanganan

\begin{tabular}{ccc}
\hline Penanganan & n & \% \\
\hline Operasi & 47 & 59 \\
Tidak & 32 & 41 \\
Total Data & $\mathbf{7 9}$ & $\mathbf{1 0 0}$ \\
\hline
\end{tabular}

\section{BAHASAN}

Penelitian yang pernah dilakukan pada tahun 2011, diagnosis cedera kepala yang datanya diambil di RSUP Prof Dr. R. D. Kandou Manado berjumlah 97 kasus cedera kepala. Oleh karena kepentingan penelitian, beberapa kasus dikeluarkan karena tidak memenuhi kriteria inklusi peneliti. Dari 79 kasus yang memenuhi kriteria inklusi, 58 kasus merupakan kasus cedera kepala ringan, 17 kasus cedera kepala sedang, dan 4 kasus cedera kepala berat.

Berdasarkan data yang diperoleh dari bagian Rekam Medik BLU RSUP Prof. Dr. R. D. Kandou Manado periode 2012 - 2013 ada 206 pasien cedera kepala. Sebanyak 105 kasus cedera kepala ringan, 64 kasus cedera kepala ringan, dan 37 kasus cedera kepala berat. Dari 105 kasus cedera kepala ringan yang ada, hanya 89 kasus yang memenuhi kriteria inklusi penelitian.

Berdasarkan data tabel 1 dari 89 kasus yang ada, sebanyak 68 orang (76\%) berjenis kelamin laki-laki sedangkan perempuan berjumlah 21 orang (24\%). Dengan demikian, laki-laki lebih banyak mengalami cedera kepala dibandingkan dengan perempuan. Distribusi Soetom (2002), distribusi kasus cedera kepala lebih didominasi oleh kaum laki-laki dibandingkan dengan perempuan. $^{2}$ Cedera kepala sebagian besar terjadi pada laki-laki karena laki-laki lebih aktif secara fisik dibandingkan perempuan, selain itu laki-laki juga memiliki perilaku yang cenderung beresiko mengalami cedera. $^{3}$ Hal ini dikarenakan laki-laki lebih sering berada dalam keadaan yang berbahaya seperti mengendarai kendaraan bermotor, perkelahian, buruh bangunan, bahkan berada di tempat-tempat tinggi untuk memperbaiki sesuatu. Sedangkan pada umumnya berada di lingkungan yang aman dan jauh dari resiko cedera kepala.

Data pada Tabel 2 menunjukkan bahwa yang paling banyak mengalami cedera kepala ringan adalah kelompok umur $>15$ 20 tahun dengan jumlah penderita 23 orang (26\%). Kelompok umur $>40-45$ tahun dan $>55$ - 60 tahun adalah yang paling sedikit mengalami cedera kepala dengan jumlah 2 orang (2\%). Distribusi Soetom (2002), distribusi kasus cedera kepala terutama melibatkan kelompok usia produktif antara 15-44. ${ }^{2}$ Kelompok umur $>15-20$ tahun sangat rentan dengan keadaan yang beresiko tinggi cedera kepala seperti kecelakaan lalu lintas dan perkelahian. Selain itu, di umur yang masih muda tersebut tingkat kematangan emosional masih belum stabil sehingga mudah terlibat dalam keadaan yang beresiko mengalami cedera kepala.

Berdasarkan distribusi penderita cedera kepala ringan berdasarkan penyebab pada tabel 3 menunjukkan bahwa kecelakaan lalu lintas (KLL) merupakan penyebab yang paling banyak dengan jumlah 65 kasus ( 73\%). Lebih dari 70\% pasien yang terlibat dalam kecelakaan lalu lintas menderita cedera kepala. Kecelakaan lalu lintas dapat mengakibatkan berbagai cedera. Cedera yang paling banyak terjadi pada saat kecelakaan lalu lintas adalah cedera kepala. ${ }^{7}$ Cedera kepala akibat kecelakaan lalu lintas merupakan penyebab utama disabilitas dan mortalitas di negara berkembang. ${ }^{7}$ Keadaan ini umumnya terjadi pada pengemudi motor tanpa helm atau memakai helm yang kurang tepat dan yang tidak memenuhi standar. ${ }^{7}$ Kontribusi paling banyak terhadap cedera kepala serius adalah kecelakaan sepeda motor, dan sebagian besar diantaranya tidak menggunakan helm atau menggunakan helm yang tidak memadai $(>85 \%){ }^{8}$

Data pada tabel 4 menunjukkan dari 89 kasus cedera kepala ringan, hanya 10 kasus dengan hasil CT Scan kepala normal sedangkan 79 kasus hasil CT Scan yang abnormal. Dari 79 kasus dengan CT Scan abnormal, intracranial haemorrhage (ICH) 
Manarisip, Oley, Limpeleh; Gambaran CT Scan Kepala pada Penderita Cedera Kepala...

merupakan gambaran CT Scan abnormal yang paling banyak dengan jumlah kasus 30. Di urutan kedua ada lesi multiple dengan jumlah kasus 25. Gambaran yang paling sering pada lesi multiple adalah gabungan dari ICH dan EDH. Jika dibandingkan dengan penelitian sebelumnya, gambaran CT Scan abnormal yang paling sering didapati ICH dengan persentase 34,5\% yang hanya berbeda $0,5 \%$ dengan hasil penelitian ini yang berjumlah $34 \%$. Dari 30 kasus dengan gambaran ICH, sebanyak 12 kasus memiliki gambaran ICH di regio temporalis, 13 kasus di regio frontalis, 2 kasus di regio frontobasalis, 2 kasus di regio occipital, dan 1 kasus di regio temporopariental. Hal ini sesuai dengan kepustakaan yang ada dimana ICH terutama melibatkan lobus frontal dan temporal $(80 \%-90 \%){ }^{8}$

Data yang tersaji dari Tabel 5 menunjukkan distribusi penderita cedera kepala ringan berdasarkan penanganan yang diberikan. Untuk 10 penderita dengan gambaran CT Scan kepala normal diberikan penanganan konservatif. Sedangkan 79 penderita dengan gambaran CT Scan kepala abnormal, sebanyak 47 penderita dilakukan penanganan operatif dan 32 penderita tidak dilakukan operatif. Hampir semua penderita yang tidak dilakukan tindakan operatif dikarenakan penderita menolak untuk dilakukan tindakan operatif dan memilih untuk pulang.

\section{SIMPULAN}

Berdasarkan hasil penelitian yang dilakukan selama periode Januari 2012 Desember 2013 dapat disimpulkan bahwa Pasien cedera kepala ringan yang paling banyak adalah laki - laki sebanyak $76 \%$. Pasien cedera kepala ringan yang paling banyak pada kelompok umur $>15$ - 20 tahun sebanyak $26 \%$.

Penyebab cedera kepala ringan yang paling sering adalah kecelakaan lalu lintas sebanyak $73 \%$. Sebanyak $11 \%$ pasien cedera kepala ringan memiliki hasil CT Scan dengan gambaran yang normal, sedangkan gambaran CT Scan abnormal yang paling banyak adalah ICH sebanyak 34\%. Dari 79 kasus dengan gambaran CT Scan yang abnormal, sebanyak 59\% dilakukan tindakan operasi dan 41\% tidak dilakukan tindakan operasi. Sedangkan untuk 10 kasus dengan gambaran CT Scan yang normal diberikan penanganan konservatif.

\section{SARAN}

Perlu disosialisasikan kepada masyarakat mengenai cedera kepala ringan mengingat kasus cedera kepala ringan merupakan kasus cedera kepala yang paling banyak terjadi. Kesadaran masyarakat akan tingkat keselamatan dalam berkendara perlu ditingkatkan mengingat kecelakaan lalu lintas menjadi penyebab utama cedera kepala. Perlu juga disosialisasikan kepada masyarakat dan para medis mengenai pentingnya melakukan pemeriksaan CT Scan mengingat gambaran CT Scan kepala abnormal banyak terjadi pada kasus cedera kepala ringan.

\section{UCAPAN TERIMA KASIH}

Ucapan terima kasih ditujukan kepada dr. Maximillian Oley, Sp.BS dan dr. Hilman Limpeleh, SpB selaku pembimbing skripsi dan semua pihak yang baik secara langsung maupun tidak langsung yang telah menumbuhkan ide dan gagasan bagi penulis.

\section{DAFTAR PUSTAKA}

1. Japardi I. Penatalaksanaan Cedera Kepala Secara Operatif. 2005. Available from http://library.usu.ac.id/download/fk/bedahiskandar\%20japardi61.pdf

2. Ekapurnama. Asuhan Keperawatan dengan Klien Cedera Kepala Berat. Available from http://digilib.unimus.ac.id/files/disk1/108/jt ptunimus-gdl-ekapurnama-5391-1-babi.pdf

3. Nurfaise. Hubungan Derajat Cedera Kepala Dan Gambaran CT Scan Pada Penderita Cedera Kepala Di RSU dr. Soedarso Periode Mei - Juli 2012. 2012. Available from jurnal.untan.ac.id/index.php/jfk/ article/download/1778/1726

4. ADVANCED TRAUMA LIFE SUPPORT FOR DOCTORS. $7^{\text {th }}$ EDITION. 2004

5. Irawan H, Setiawan F, Dewi, Dewanto G. Perbandingan Glasgow Coma Scale dan 
Jurnal e-CliniC (eCl), Volume 2, Nomor 2, Juli 2014

Revised Trauma Score dalam Memprediksi Disabilitas Pasien Trauma Kepala di Rumah Sakit Atma Jaya. Majalah Kedokteran Indonesia. 2010. Available from http://indonesia.digitaljournals.org/ index.php/idnmed/article/download/.../745

6. Satyanegara. Cedera Kepala dalam Ilmu Bedah Saraf. Edisi Ketiga. Jakarta: PT. Gramedia Pustaka Utama; 1998. hal. 9, 147-76 Available from books.google.co.id/ books?isbn=9792264787
7. Nasution N S. Karakteristik Penderita Cedera Kepala Akibat Kecelakaan Lalu Lintas Yang Rawat Inap di RSUD. Padangsidimpuan tahun 2005-2007. 2008. Available from http://repository.usu.ac.id/ bitstream/123456789/16495/5/Chapter\%20 I.pdf

8. Iskandar J. Cedera Kepala : Memahami Aspek - Aspek Penting dalam Pengelolaan Penderita Cedera Kepala. Jakarta: Buana Ilmu Populer; 2005. H. 8-9, 17-22. 